\title{
THE (IR)RELEVANCE OF BIBLICAL SCHOLARSHIP? A CHALLENGE, AND AN OPPORTUNITY
}

\author{
Benjamin D Giffone \\ Old and New Testament \\ Stellenbosch University \\ Faculty of Theology, LCC International University
}

\begin{abstract}
Has biblical scholarship become irrelevant to modern secular societies? Are the threats to the viability of biblical scholarship of the same nature as the threats to other areas of the humanities (history, philosophy, literature), or is there a qualitative difference? What about the role of technology in biblical research and biblical education? What is the future of the institutions of biblical scholarship such as universities, seminaries, journals, and academic presses? What is the role of biblical scholars in secular and post-secular societies, as contrasted with scholars in/from emerging communities? This essay argues that the problem of "validation" lies at the heart of biblical scholarship's irrelevancy within the broader secularity of modern world and that this problem is even more evident in the scholarly discourse coming from regions like Eastern Europe and South Africa. However, the loss of authority of biblical scholarship more generally represents an opportunity for these communities. Rather than becoming enamoured of validation from the North Atlantic world, Bible-reading communities must cultivate their own forms of validation based in their unique histories with the Bible, and the affinities between their own histories/cultures and the cultures that produced the Old and New Testament texts.
\end{abstract}

Keywords: Relevance of biblical scholarship; (Post-)Secular society; Eastern Europe; South Africa; Biblical research; Biblical education

\section{Introduction}

This series of essays arose from an intimate gathering of biblical scholars in Klaipeda, Lithuania, following the international SBL meeting in Helsinki, August 2018. The impetus for this small meeting was the question of the role of the Bible and biblical scholarship in societies that might be called "secular" or "post-secular."

It was my honour to serve as organiser and institutional host to this conversation, which, due to location and personal connections turned out to be a fruitful exchange, mainly between scholars from South Africa and scholars who come from — or are based in-Eastern Europe. This issue of Scriptura includes some of these papers and other contributions solicited later from scholars in both regions.

It is important to identify myself as a friendly, respectful outsider to both communities/regions. I was raised in the United States, completed master's and doctoral degrees in South Africa (Stellenbosch), and have served on the faculty of an Englishspeaking, private, North-American-style Christian university in Lithuania since 2014. I 
maintain academic and personal relationships with colleagues in both South Africa and Eastern Europe, as well as in Western Europe and North America.

My "outsider" status leads me naturally to make comparisons between the two regions and between their shared points of contrast with Western Europe and North America (what I will hereafter refer to as the "North Atlantic" world). Biblical scholarship faces challenges within our "secular" age that are in some ways unique within the broader academy. Additionally, the challenges of biblical scholarship in Eastern Europe and South Africa differ from those of the North Atlantic world.

In this essay, I describe some of the current challenges to biblical scholarship, particularly in Eastern Europe and South Africa in comparison to Western Europe. In places I have painted an overly bleak picture of the situation, adopting a gently hostile stance, so that the place of our field in society can be evaluated critically. What indeed is the use of biblical scholarship, and why (and how) should it continue in Eastern Europe and South Africa?

\section{The Bleak State of Biblical Scholarship?}

How healthy is the field of biblical scholarship today? A guest at the international SBL meeting in Helsinki (2018) might well have believed that, at least in the North Atlantic community, biblical scholarship is alive and well. Hundreds of professors, researchers, educators, graduate students, and publishers converged at the University of Helsinki to share research and ideas. The University itself, as was explained at the opening reception, has a robust academic program in biblical studies (world-renowned), as well as several relevant research Centres of Excellence established by the Academy of Finland. More broadly, one might observe the difference between our "senior" colleagues' descriptions of the SBL meetings a generation ago and the meetings today. In terms of overall attendance and the diversity of views and backgrounds represented at those meetings, the comparison is stark. In terms of publishing, there are more journals and academic series than ever before, and it is much easier to conduct and to share research than ever before. By these measures, it is a good time to be a biblical scholar.

And yet it is also possible to tell a different story about the state of biblical scholarship in these societies in which some scholars seem to be flourishing. The Bible itself, and religion more generally, appear to be playing less of a role than ever before in public and private life - this is one component of the "secular" definition. Rates of biblical literacy are low, as is church/synagogue attendance. ${ }^{1}$ To the extent that the Bible is used in public discourse at all (as it often is in my native country, the United States), it is surface-level engagement at best. $^{2}$

As I myself participated in the Helsinki meeting, I was inspired by the high erudition and meticulousness of my fellow scholars. Our profession selects for intelligence and diligence. But I have to honestly say how hard it is to articulate just how society at large benefits from much of what we (collectively) do. Why do we exist, and where are we going? How do the sources of funding for our scholarship affect what we study and how

Numerous surveys by interested groups can be cited. Here are a few representative examples demonstrating the decline: Australia - Lake (2018); United States - Stetzer (2015); Europe - Statista Research Department (2020).

2 Out of myriad examples in recent history, a prominent example would be the use of Romans 13:1-7 to justify particular policies concerning the treatment of illegal immigrants (Mullen 2018). 
we present it to the world? Is biblical scholarship fundamentally the same as other disciplines of historical or literary studies, or do we have unique challenges and responsibilities?

\section{Defining “Biblical Scholarship”}

How does one explain the job description of a biblical scholar to someone without any knowledge of the existing institutions of scholarship? "So, what do you do?" "I'm a biblical scholar." "What-like a priest?" Even many devout Christians and Jews, "people of the book", have no knowledge of biblical scholarship. At the university where I teach, a private Christian liberal arts university, many of our students come with no knowledge about the Bible, let alone any idea that it could be a field of professional academic study. ${ }^{3}$

Fundamentally, biblical scholarship might be thought of as a dual task: generating insights and sharing insights. Generating new insights consists of uncovering new data, and reinterpreting and reapplying existing data or truths according to new methods and/or in new contexts. Sharing insights includes teaching students (insights shared and explained) and writing (insights encapsulated and presented across time and space).

This process serves at least three purposes. In communities of faith, biblical (and theological) scholarship can serve to connect us to God by helping us to understand the scriptures which we accept as revelatory. Some of us originally chose the path of biblical scholarship because we found ourselves in agreement with these words of the Apostle Peter: "Lord, to whom shall we go? You have the words of eternal life" (Jn 6:68). Second, the process of biblical scholarship serves to help non-specialists appreciate the Bible as they would appreciate other influential works of art, literature, history or philosophy. Third, biblical scholars speak to other specialists, sharpening one another's thinking, and training new generations of specialists.

Why do we generate new insights about ancient texts? Why not simply teach the old insights? It is easier to understand why we would seek to generate new insights in the natural sciences or the social sciences. But in the humanities, new "discoveries" are made at a very slow pace. Tangible discoveries with the potential to reshape the field of Shakespeare studies are not very frequent; that sub-discipline exists mainly to preserve and promote existing knowledge of a fixed corpus of literature that has been judged to be beautiful and significant.

We might think of biblical studies and cognate fields as having this sort of "museum" function: preserving and sharing knowledge about the ancient world. In an art museum, public or private funds are donated to specialists who preserve, restore and promote beautiful things simply for the benefit of humanity. Similarly, departments of ancient studies, history, literature, philology, philosophy, or religion might preserve, share and publicise the texts that we study as historical artifacts. Occasionally, new discoveries, such as the Qumran scrolls, change our field, but most of the time, we are working on

LCC International University is a private Christian liberal arts university, offering a North-American style of education in English that trains students for servant leadership. At most public and private universities in Europe, typically students take courses in the Bible (either Bible from a creedal/confessional perspective, or Bible as literature) because they choose to do so for personal edification or professional preparation. We have a unique situation at LCC where many of our students who might not otherwise choose to take Bible courses, must take two semesters of Bible in the core curriculum. 
the same set of objects that do not change.

It may be possible to morally justify using tax revenue (extracted from productive citizens by threat of force) to fund the preservation and sharing of biblical and related texts. But how many scholars does humanity need in order to "preserve texts"? One might imagine, for example, that perhaps one or two hundred scholars would be more than sufficient to preserve humanity's knowledge of Akkadian language and literature. This would not require very much in terms of humanity's resources - relatively fixed endowment for salaries and preservation of tangible artifacts, and the opportunity cost of intelligent people diverted from other productive tasks. If we are strictly funding preservation of knowledge, those costs should decrease in absolute terms (as technology improves) and in relative terms (humanity needs the same number of Akkadian scholars whether the global population is 3 billion or 7 billion). As long as each Akkadian professor mentors one or two $\mathrm{PhD}$ students every thirty years to ensure that he or she has a replacement, the knowledge is preserved.

Incentive structures in the academic cultures of North Atlantic scholarship tend to pull our priorities away from preservation (saving texts in museum-like fashion) or education (presenting known insights compellingly), and toward "generating new insights": articles, conference papers, and books. These insights take different forms or directions in scholarly communities supported by public funds, by private philanthropy, or by communities of faith. Public, philanthropic, and religious institutions fund the production and promulgation of new insights because these constituencies believe that the texts we study do (or should) play a critical role in the public sphere. The legacy of Judaism and Christianity in the North Atlantic world means that the Bible is still important to who we are, even if we do not always understand exactly how.

Our field is therefore not exactly like other divisions of the humanities. Public and private entities recognise that the significance of biblical texts goes beyond mere preservation. Religious texts matter to people's lives - more directly than the question of how Alexander the Great was able to successfully defeat the Persian Empire, more than the works of Goethe. Thus, we must recognize that we contend for and over the biblical texts, and we must acknowledge the effect of these struggles (and the litigants who line up behind us with funding) on our scholarship.

\section{Unique Challenges of Biblical Scholarship Within the Humanities}

When it comes to sharing insights with non-specialists-i.e., teaching-we also face unique challenges. I can commiserate with my colleagues who teach history and literature about how hard it often is to inspire our students. We may circulate jeremiads concerning the current state of humanities education: young people can't read texts or don't care to read them; reading on screens is shortening attention spans; search engines are rendering them (and us) unable to remember anything; students are only fulfilling a requirement to get a BA for a job; they cannot think critically or write an essay. Additionally, the internet has moved the cost of publishing close to zero, so there is more junk out there for students to sift through — and many are unable to do so critically. Those of us who care about art, history, literature and philosophy can each remember a teacher who initiated us into the world of ideas and beauty, and inspired us to be educators 
ourselves, so these developments grieve us. ${ }^{4}$

Here also, the challenges of biblical scholarship are qualitatively different from those of the other humanities disciplines. Because the Bible is still relevant to the lives of many deeply religious people, they produce popular content about the Bible. This content may be interesting, but most of it has not passed through any kind of rigorous review process by academic gatekeepers. We would never think to cite as a source in a paper an internet writer who shared "insights" about ancient Assyria or Goethe's Faust that "came to them" in their dreams, and not many folks feel passionate enough about those subjects to produce online content explaining them. Yet folks without formal training, who often feel they have been given insight by the Holy Spirit into the Scriptures, can present their teachings to others with minimal or zero publication cost. Our students then find those works, which support their limited understanding of the Bible, and never encounter rigour - even rigorous scholarship that might actually support their faith position. Thus, the Bible continues to exert an influence at a popular level apart from the validation processes of the academy.

\section{North Atlantic Scholarship: Undue Influence?}

Finally, what is the responsibility of biblical scholars who belong (partially) to "legacy communities of faith" in secular and post-secular societies? Can we who come from the "North Atlantic" world be entrusted with the responsibility of "generating new insights" in our discipline? One could make the case that Christianity has "lost" (or at least "stalled") in our societies, and we should step aside and yield the floor to scholars from countries where belief and interest in the texts is thriving. Our South African colleagues have much to say in this respect, but of course each of the nations represented by our contributors have at least pockets of vibrant faith and interest in the Bible. However, validation, funding, and research priorities still come from the North Atlantic world, despite the decline in rates of religious identification and adherence in North Atlantic nations.

How can we dwell on and share what is good and helpful and edifying about the North Atlantic legacy of scholarship while at the same time letting that which is not edifying fall away into obscurity? Moreover, who is positioned to decide what should and should not "last"?

\section{History of "Biblical Scholarship": A Few Key Moments}

While the roots of modern biblical scholarship are myriad and complex, several key moments and movements deserve attention. Though of course Christian (and Jewish) communities of faith may be found all over the world, developments in Western Europe since the Reformation have had an outsized influence on scholarship that continues down to the present. Indeed, one challenge faced by scholars and religious communities in

\footnotetext{
However, surveys seem to indicate that those of us who were inspired by educators to pursue culture for its own sake - likely readers of these essays - are quite unusual. Bryan Caplan (2018, especially ch 9, 238-261) demonstrates the ineffectiveness of this "turn philistines into humanists" role of formal education: educators are remarkably ineffective at inspiring students' desire to consume high culture or to affect their political or religious views through liberal education. While Caplan's study focuses specifically on the American situation, his work seems applicable more broadly in educations systems modeled after various European approaches to education.
} 
Eastern Europe and South Africa may be articulated as: how to receive (or reject) the legacy of Western European scholarship.

\section{From the Reformation through the 19th Century: The "Cultural Bible"}

Among many others, Legaspi (2010) has traced the rise of "biblical studies" as a field in its own right, separate from "theology" done in strictly confessional contexts. A crisis of authority emerged from the Reformation: the dislodging of the Catholic Church as the sole authority in the West moved the Bible itself to the centre of the battlefield between Protestants and Catholics. The Bible thus became an object over which conflicting traditions disputed - not simply Protestant and Catholic confessions, but also scholastics and humanists (Legaspi 2010:4). From these (at times armed) conflicts, a new type of study of the Bible emerged:

What developed in the mid-eighteenth century was not a new awareness of the 'human' or 'historical' character of the Bible. Rather, it was the realization that the Bible was no longer intelligible as scripture, that is, as a self-authorizing, unifying authority in European culture. Its only meanings were confessional meanings: Catholic, Lutheran, Reformed. If the Bible was to find a place in a new political order committed to the unifying power of the state, it would have to do so as a common cultural inheritance (Legaspi 2010:5).

The "cultural Bible" was amenable to scholars with varying degrees of adherence to a range of confessional viewpoints. The Enlightenment further facilitated a shift away from the Bible as basis of truth toward the study of the Bible based on methods and criteria external to it. Politically, the "cultural Bible" fit the mission of the German universities founded during the Enlightenment: "the aims of a strong central government to create a new institution in direct service of a 'deconfessionalized' state" (Legaspi 2010:40). Like classical Greece and Rome, the Bible could become a resource of moral and cultural imagination for a new sort of civil servant (Legaspi 2010:43).

The "cultural Bible" mode of scholarship made great progress during the $19^{\text {th }}$ century, which saw many new archaeological finds that could be brought to bear on the study of the text. Even as devout believers saw in this new mode resources that could be compatible with confessional study of the Bible and integrated into "theology" traditionally understood, it was no longer a given that "biblical studies" would necessarily be so integrated. Thus developed the modern tension between so-called "critical" approaches, which methodologically held supernatural claims of the biblical texts at arm's length, and "believing" approaches, which accepted the Bible's supernatural claims. ${ }^{5}$

The widely-cited example of Wellhausen aptly illustrates this uneasy relationship between traditional faith communities and critical modes of scholarship developing from the Enlightenment. In 1882, Wellhausen famously resigned his professorship at Greifswald, which required him to teach Old Testament as part of students' training for ministry in the state Lutheran church, on the grounds that, "in spite of all the discretion of which I am able, I cause my hearers to become unfit for their occupation"- - a situation

See the helpful survey in Rogerson (1984). 
which had "weighed seriously upon my conscience."

Having found a "faculty of theology" to be an inappropriate context for his scholarship, he found a home in the faculties of philology (at Halle, Marburg, and Göttingen) as a professor of oriental languages, producing important works on Arabic language, history and culture. Little did he know that his approach to the Old Testament would become a significant paradigm that would dominate the field for decades afterward, even in faculties of theology. The point is neither to valorise nor denigrate Wellhausen - nor to single him out-but rather to compare the ways that the communities of faith and scholarship negotiated these tensions, then and since.

\section{The 20th and 21st Centuries: Plurality and Fragmentation of Knowledge}

In the $20^{\text {th }}$ century - especially the post-War period continuing into the early $21^{\text {st }}$ century - we saw innumerable changes, even revolutions, in biblical scholarship. It will suffice to characterise some of the results that are relevant for the present conduct of scholarship in our field.

The economic prosperity of the West, unparalleled in human history (but not always enjoyed by South Africans and Eastern Europeans), brought with it many benefits for academics generally and for biblical scholarship in particular. Increased demand and funding for university education meant more demand for professors to teach, not just in the "sciences" but also in the humanities. Individuals who had previously been excluded - formally or tacitly - from university studies because of gender, class, race, ethnicity, or system of belief began to rise through the university system.

There is also new data in our field to be evaluated. Public and private funding for archaeology and shifting political situations in the "Near East"/Southwest Asia provided new discoveries, both texts and material evidence, that then influenced interpretation of biblical texts. One need only consider the implications of the Qumran texts for both Old and New Testament studies to affirm this point.

In addition to new identities, backgrounds and confessional beliefs entering in the scholarly conversation, the $20^{\text {th }}$ century also saw a proliferation of new methods and approaches in biblical scholarship drawn in from other fields: history, philosophy, linguistics, literary studies, the social sciences, and more. These include approaches that are in some sense an extension or continuation of the historical-critical enterprise that emerged in the $18^{\text {th }}$ and $19^{\text {th }}$ centuries in Europe - and also postmodernism's deconstructive and identity-shaped readings. ${ }^{7}$ Funding and technology have amplified these many voices, and have both extended and focused such conversations, which are carried out in scholarly venues such as monographs, journals and academic conferences. Prosperity has allowed the West the luxury of fairly specialised endowed chairs, research professorships, research centres, etc., to study matters of human interest that would not have been possible to study in previous eras (and is still not possible for many today). Whereas previously the cost of publishing was prohibitive and a few gatekeepers controlled what entered into scholarly discourse, technology has driven the cost of presenting research through books and journals close to zero.

Consequently, the last few decades have seen a proliferation of journals that

Quoted in Carbajosa (2013,:30, fn. 16).

See the excellent overview of Collins (2005). 
specialise in particular biblical or related subject matter (Pauline studies, Ugaritic studies) or particular approaches (semiotics, Feminist approaches). Biblical scholarship since at least the $18^{\text {th }}$ century has wished to understand itself as being in some sense wissenschaftlich, like other fields of study. Postmodernism has perhaps broken through the veneer of the Wissenschaftlichkeit of some of these approaches and even revelled in their "unscientific-ness."

The present situation of biblical scholarship is at once incredibly dynamic, diverse, and interesting - and also fragmented, opaque, and minute. Anyone in our field who doubts this point should pick up a recent issue of the Journal of Biblical Literature, read an essay at random (or pick at random a session at the SBL Annual Meeting), and ask herself whether she could offer meaningful peer review of that essay or even if the essay would have any bearing on her own scholarly projects. A biblical scholar who is conversant in one set of methods in one sub-field may have almost nothing interesting to talk about with her colleague who is technically in "biblical studies" but works with different methods in a different sub-field.

\section{Secularity and the New "Priesthoods" of Modernity}

Today, while our conversations continue along apace in the academy, the public increasingly looks to resources other than the Bible - and to leaders other than biblical scholars and theologians-for inspiration, morality, and telos. The traditional "priesthoods," institutions that have been tasked with studying and expositing the Bible, are viewed as compromised by colonialism, complicity with repressive states and ideologies, widespread hypocrisy on fundamental issues of morality, and abuse within their own structures.

Parallel to the development of the scientific revolution with its compelling explanatory power has been the loss of trust in religious authorities and metanarratives. In a sense, this could be understood as the second of Charles Taylor's (2007) three "secularities": a retreat of belief in the face of scientific progress. But even with moves toward a "post-secular" age - an awareness of the transcendent - in contemporary Western society, the tendency is to look to scientific (scientistic?) or artistic voices. These new elites and their metanarratives, while not morally (or scientifically ${ }^{9}$ ) unproblematic, are perceived as having led large segments of humanity into a new phase of abundance, away from the scarcity that has governed nearly all of human existence. The priests of secular society are economists, philosophers, climate scientists, medical doctors, public health officials, psychologists, and politicians. These priests not only produce, maintain, and selectively dispense opaque knowledge thought to be essential for human existence; they also promulgate normative visions of morality and of flourishing - they are prophets, as well as priests.

These visions are generated in academic venues and then communicated in popular formats such as trade books, podcasts, popular fiction, television and film. Science fiction in particular, understood broadly to include comics/graphic novels and films

See an important conversation concerning Habermas's work on the "post-secular," in Habermas et al. (2010).

I am thinking here of the well-known "replicability crisis" that currently plagues the social sciences (especially psychology) and also the field of medicine. See, for just the tip of the iceberg, Farid Anvari and Daniël Lakens (2018:266-86); Psychology Today (2021). Likewise, medical sciences are experiencing a crisis of trust, noted here by the former editor of the British Medical Journal in its opinion blog (Smith 2021). 
based on them, is now the main genre that produces fictional narratives reflecting and shaping human self-understanding, purpose, and morality. Pop-culture figures, such as podcasters and online influencers, perform the evangelistic and gatekeeping functions by providing platforms for simplified versions of academic "truths." We may also observe the hyper-individualisation of knowledge and values due to algorithms ostensibly developed to help consumers navigate the burgeoning sea of material, but which have instead produced echo chambers and parallel, irreconcilable understandings of fact and meaning (Kalpokas 2019).

Thus, the modern secular project has left biblical scholars-despite being more numerous, more diverse, and more prolific than we have been in previous generationswithout a decent seat at the table, let alone being "in the driver's seat" as theologians had been in medieval Europe. Some biblical scholars are content to be relegated to the margin of public discourse, operating within the "cultural Bible" or "museum" model of scholarship. Other biblical scholarship strives to be "relevant" to various domains of secular society in that the Bible is sometimes "grafted into" these domains and their prophetic visions - a move often welcomed or even initiated by the "priests" of these domains. Biblical texts (and sometimes, scholars to expound them) are summoned in support of various economic models, political liberation and social inclusion, and environmental apocalypticism (or optimism); as containing moral examples or wisdom, or even as windows into the human psyche. But the Bible's stories and worldviews are not generally permitted to critique or exert any controlling influence beyond broadly confirming or supplementing what the priests of the "real world" have said.

\section{Biblical Scholarship Beyond the North Atlantic World}

Outside the North Atlantic world, however, the influence of the Bible appears to be increasing - at least if measured by the number of people who identify as Christian and claim the Bible as an authority. Structural realities therefore affect biblical scholarship in the Majority World; a few in particular stand out as relevant for both South Africa and Eastern Europe.

First, resources for biblical research-tangible books and artefacts, university programs, and funding - remain concentrated in Western Europe, North America, Australia and New Zealand, and Israel. Despite the fact that research can be shared electronically at virtually no cost, North Atlantic publishers still maintain books and journals behind paywalls that cannot be unlocked by small universities and seminaries, let alone by independent researchers paying for their own resources. Thankfully, a great deal of public attention has been focused in recent years on increasing access to (often publicly-funded!) research. Initiatives such as open-access journals and SBL's International Cooperation Initiative are steps in the right direction. But some resources cannot be shared effectively electronically (e.g., manuscripts, artefacts, out-of-print publications), or will not be made open-access anytime soon. Hence, we also observe the inevitable emergence of sites that exist to share scholarly materials illegally; these sites cannot be fully suppressed due to domain-hopping, and it is unclear whether the researchers themselves would want to see such sharing suppressed.

But simply accessing PDFs is not sufficient for effective writing and teaching. Research requires free time and travel to conferences for presentation and networkingpaid for by stipends, salaries, grants, and bursaries. The costs of travel to Europe or North 
America for conferences or visits to research libraries are significant enough for independent researchers or graduate students in those regions - but such costs are even more prohibitive for researchers in countries with yet-emerging scholarly communities.

Scholarships provided for international students to study in the North Atlantic world, and initiatives like SBL's International Travel Awards Program (ITAP) and the Langham Partnership, serve to shift some of the wealth of the West to less-affluent countries. ${ }^{10}$ This leads to the second challenge of Majority World biblical scholarship: the continuing dependence, influence, and validation of the North Atlantic world. It has long been the practice of non-Western-European faith communities (as we will see in other essays) to send their brightest and best to Western Europe to be trained in biblical and theological studies. While this pattern is understandable (and perhaps necessary initially), it can result in a form of theological colonisation and even colonialism, whereby Majority World scholars are welcomed in North Atlantic communities but must still have their scholarship validated by North Atlantic institutions (universities, journals, publishers). Institutions within the Majority World celebrate their students, who subsequently go on to graduate study in Europe and North America, and showcase their faculty who have been trained abroad. These Emerging World institutions' own graduate programs must work for decades to earn recognition (once again, from the North Atlantic world!) for their graduates, and typically never achieve the international prestige of programs in the North Atlantic world.

In some cases, funding for scholars from the Majority World is specifically designated for methods or topics that reflect North Atlantic scholarly agendas. For Majority World scholars, these topics can sometimes be irrelevant at best and patronising (literally!) at worst. Here is one illustrative example: while serving as a visiting professor at a small seminary in Ukraine, I worked closely with a young graduate of that seminary, my interpreter, who himself hoped to go on for doctoral studies. He had received a bachelor's from this seminary and a master's from an evangelical seminary in Western Europe; in addition to Russian, Ukrainian and English, he had proficiency in the biblical languages and relevant Western European languages. He was bright and well-positioned to return to this seminary in Ukraine and teach Russian-language graduate courses to prospective pastors who might not easily access Western scholarship. Upon his acceptance to a $\mathrm{PhD}$ programme in a North Atlantic institution, however, he was only offered funding if he agreed to write on ecological readings of the Hebrew Bible - an approach that did not interest him and would not prepare him particularly well for teaching Hebrew and a full slate of canon courses at a small seminary in Ukraine.

Alternatively, a student from a Majority World community is tacitly (or explicitly) expected to bring to North Atlantic circles "The __ Perspective," i.e., whatever "othered" identity he or she represents. Such a student must simultaneously learn to be conversant in North Atlantic discourse in order to be heard, and while also representing a perspective that is identity-based - ideally, a perspective sufficiently "exotic" for white scholars of European descent. The "defaults" of critical biblical scholarship are still white and English- or German-speaking; "other voices" remain so, "other."

These relationships between the North Atlantic world and the Emerging World also perpetuate the norm of scholarly discourse in European languages, thereby hindering the

10 Several of this issue's contributors have connections to the ITAP programme and/or the Langham Partnership. 
development of robust scholarly literatures (or popular dissemination of research) in other national and regional languages. ${ }^{11}$

\section{South Africa and Eastern Europe in Conversation}

As acknowledged at the outset, I have painted an overly dark portrait of the state of biblical studies, particularly of the relationship between North Atlantic scholarship and the rest of the world. It is possible to highlight past injustices and present dysfunctions to legacy systems without ascribing motives to individuals who operate within them. There are presently bright spots within our field, as well as many productive relationships and paths forward that can be suggested.

Several collections in recent years have served to bring European and African biblical scholars into dialogue with one another, sometimes alongside other global voices. The editors of one such collection begin their introduction:

What does Africa have to say to Europe and Europe to Africa about the bible? There is plenty to say, for the bible binds us to each another [sic]. Not only did the bible come to Africa from Europe, but most African scholars have been trained in Europe or by Europeans. Europe has thus fundamentally shaped biblical interpretation in Africa, especially among African scholars. But to imagine that Africa is the object and Europe the subject in conversation would be wrong, for Africa has appropriated the bible as its own book and African biblical scholars have been re-trained by ordinary African readers of the bible. The result is that African biblical scholarship has developed its own identity, constituted partly by its European origins and partly by its African location. (De Wit, Snoek, and West, eds.:2008:ix-xiv, here ix).

Notably absent from this volume, though, are voices from Central or Eastern European contexts or backgrounds (only the Netherlands and Norway). Another collection of "global voices" contains only one essay from Eastern Europe (Kirova 2012:99-110). A recent journal article presents the contributions of Georgian biblical scholarship to the wider world, mainly focusing on its relevance for textual criticism and Septuagint studies (Dundua and Mirotadze 2020:5-18).

\section{Regions in Conversation}

To those who are less familiar with the recent histories of South Africa and Eastern Europe, the rationale for such a dialogue might not be immediately obvious. Yet there are some notable points of comparison. Both regions have established traditions of Christianity, as well as Jewish minority communities. Significantly, both regions are presently shaped by recent memory of significant political repression on ethnic or racial grounds - as well as struggle for political liberation realised in the early 1990s. The end of the Cold War saw both the disintegration of the Soviet Union and the end of the Warsaw Pact, with the Baltic states re-establishing statehood in 1990 and 1991. Roughly simultaneously (1991-1994), South Africa experienced the end of formal apartheid and transition to full democracy.

Now, more than a quarter-century after political liberation, South Africa and Eastern

11 Callaham (2019) and Tan and Brooks (2019) are especially sensitive to these issues. 
Europe are still renegotiating their relationships with Western/Central Europe and North America. Both regions continue to reckon with the legacy of Western European (and for the Baltics, Russian and Soviet) imperialism - evolving economic relationships in an increasingly globalised world, and also racial/ethnic and linguistic diversity. South African readers will be familiar with the complex language politics of their own nation, including both Afrikaans and English as the legacy of two periods of colonisation. Readers will note the related but distinct struggles in Eastern European contributors' accounts of biblical and theological scholarship in their own nations, which struggled for centuries to establish academic and popular literatures in national languages amid international discourse in Swedish, German, Russian, and now English.

Despite some similarities, there are also important demographic differences between these regions. In 2020, South Africa's population was over 59 million; Poland, nearly 38 million; the Baltic states combined, just under 6 million. Even more striking is the disparity in population growth and median age. South Africa has experienced annual population growth between one and two percent since 1996, and over two percent in the decades prior. The median age of South Africans is 27.6 years. By comparison, since 2000 the population has plateaued in Poland and Estonia, and Lithuania and Latvia have experienced negative growth between $0.75 \%$ and $1.55 \%$ annually over the same period. The median ages in those nations are 41.7, 42.4, 45.1, and 43.9, respectively. ${ }^{12}$

These demographic differences are significant for the cultural and economic present and future of these nations, and so for biblical scholarship and religious discourse. A large portion of the Eastern European population remembers the suppression of religion and religious practice in Soviet times and the role of religion and religious leaders in assertions of national identity. By contrast, half of South Africans have been born after apartheid; thus the role of religion and Bible-influenced discourse in both the maintenance of the apartheid system and resistance to it belong to the previous generation.

This points to another place of contrast between South Africa and Eastern Europe: whether these societies might accurately be described as "secular"- or which of Taylor's three kinds of "secularity" might apply. For South Africa, the answer I hear from our colleagues there is, "no." But Eastern European colleagues also note the continuing interest in spirituality within their countries despite the imposition of antireligious ideology in the Soviet period. The stories told by scholars from both regions also point to the gap between academic biblical scholarship and popular religious/spiritual belief and practice, and attempts to bridge that gap.

The way I have presented these issues has been shaped in my own mind by a framing question that is structural in nature, a baseline of non-existence of formal academic institutions of biblical scholarship in Lithuania during the Soviet period: why should Vilnius University have re-established a faculty of theology (not just ancient studies, religion, or philology) after 1991? Biblical scholarship was suppressed in the Soviet Union - but what use would it serve in liberated Lithuania within secular Europe? What affirmative justification might be offered by African scholars to Eastern Europe for the value of biblical scholarship in society? How has biblical scholarship survived its former use to justify apartheid, and what positive function does it currently serve in Southern

12 Source: www.worldometers.info [accessed 08 April 2021]. 
Africa? Conversely, what can Southern Africa learn from the resilience of Eastern European scholarship and its struggle to regain a voice in society after generations of repression?

\section{Questions and Possible Paths Forward}

The contributors to this issue of Scriptura grapple with many of the concerns raised herein, drawing insights from their communities' experiences of often severe structural limitations to biblical scholarship.

At a foundational level, the Bible serves as a source of religious truth that serves the public good. C. Lombaard (2021) argues that Deuteronomy 13 injects the key democratising element into the modern secularised public square: direct human accountability to God which relativises and checks earthly authority.

Another path toward renewing relevancy, highlighted by P.G.R. de Villiers, is the reinvigoration of theology (and biblical studies) through aesthetics. Theology, like much of modern culture, has become sterile, critical, and disenchanting; reversing this trendre-enchantment of theology and ethics through celebration of beauty (with goodness and joy) - provides one means of the biblical story (and stories) re-entering the public's moral imagination. ${ }^{13}$ One might find a corollary in Michaelis's $18^{\text {th }}$-century "cultural Bible" as a common resource of moral and cultural imagination.

One possibility for fruitful use of the Bible and biblical scholarship is as a shared object of examination, leading to conversation between different communities and modes of reading. Such proposals are offered by L.C. Jonker ("Intercultural Bible Reading") and M.J. Nel ("Reading the New Testament Stereoscopically"), and also in the work of E. Petrenko, highlighted in the co-authored essay about biblical scholarship in Latvia. The exercise of reading the Bible across from an "other"-from another culture, or academy/clergy/laity dialogue — can move towards peace and reconciliation, especially crucial in the national contexts in view.

Many of the issues raised in these essays can be traced back to the problem of validation: who gets to decide what readings of the Bible are acceptable, and for what aims. There is the tension between writing in international languages for the validation of scholars in other countries (mainly North Atlantic) versus cultivating a discourse in a less-spoken national, regional or local language. There is the tension between academic, confessional, and popular modes of reading the Bible, which manifests itself in the rise of confessional seminaries to compete with public university faculties deemed too liberal. Within religious movements, there are tensions between institutions and antiinstitutional impulses.

Finally, distinct from the histories of similar tensions/conflicts in the North Atlantic world of biblical scholarship, there is a strong impulse to regard endurance through persecution and adversity as a form of validation. Both South Africa and Eastern Europe have recent histories of totalitarianism and oppression; readings offered by those who endured might be privileged by communities, regardless of how such readings might sustain "validation" in the broader world of scholarship. Jewish and

13 The term "(re)enchantment" is adopted by Moberly (2018). Note also the recent work of Wright (2019, 103ff.; 205-206) arguing for an "epistemology of love," admitting the possibility of knowledge through ritual as a complement to "reason". 
Christian communities and their book(s) have been shaped by suffering (Carr 2014); therefore, Bible-reading communities shaped by suffering and oppression (and triumph) in the $20^{\text {th }}$ and $21^{\text {st }}$ centuries have a great deal to teach the rest of us.

\section{BIBLIOGRAPHY}

Anvari, F. and Lakens, D. 2018. The replicability crisis and public trust in psychological science, Comprehensive Results in Social Psychology 3(3):266-86.

Callaham, S.N. 2019. Language and world mission. In Callaham, S.N. and Brooks, W. (eds.), World mission: Theology, strategy, and current issues. Bellingham, WA: Lexham Press, 207-238.

Caplan, B. 2018. The case against education: Why the education system is a waste of time and money. Princeton, NJ: Princeton University Press.

Carbajosa, I. 2013. Faith, the fount of exegesis: The interpretation of Scripture in light of the history of research on the Old Testament. trans. Paul Stevenson. San Francisco: Ignatius Press.

Carr, D.M. 2014. Holy resilience: The Bible's traumatic origins. New Haven, CT: Yale University Press.

Collins, J.J. 2005. The Bible after Babel: Historical criticism in a postmodern age. Grand Rapids: Eerdmans.

De Villiers, P.G.R. 2021. Reading the Bible aesthetically: On reinvigorating biblical scholarship in secularised times, Scriptura 120.1 .

De Wit, J.H., Snoek, H. and West, G.O. 2008. Introduction. In De Wit, J.H., Snoek, H., and West, G.O. (eds.), African and European readers of the Bible in dialogue: In quest of a shared meaning. (Studies of Religion in Africa 32). Leiden: Brill.

Dundua, N. and Mirotadze, N. 2020. History of biblical studies in Georgia, JSCS 53:518.

Habermas, J. 2010. An awareness of what Is missing: Faith and reason in a postsecular age. transl. Cronin, C. Cambridge: Polity Press.

Jonker, L.C. 2021. Crossing boundaries: The transformative potential of intercultural Bible reading in secular/post-secular contexts, Scriptura 120.1.

Lake, M. 2018. Why our declining biblical literacy matters. The Conversation (15 April). [Online]. Available: https://theconversation.com/why-our-decliningbiblical-literacy-matters-94724.

Legaspi, M.C. 2010. The death of Scripture and the rise of biblical studies. Oxford Studies in Historical Theology. Oxford/New York: Oxford University Press.

Lombaard C. 2021. Law and faith in ancient Israel and in modern democratic statehood as search for socio-political wellbeing. Scriptura. 120.1.

Kalpokas, I. 2019. Algorithmic governance: Politics and law in the post-human era. Cham, Switzerland: Palgrave Macmillan.

Kirova, M. 2012. The future of a nonexistent past: Biblical studies in Bulgaria. In Boer, R. and Segovia, F.F. (eds.), The future of the biblical past: Envisioning biblical studies on a global key. Atlanta: SBL Press, 97-110.

Moberly, R.W.L. 2018. The Bible in a disenchanted age: The enduring possibility of Christian faith. Grand Rapids, MI: Baker Academic. 
Mullen, L. 2018. The fight to define Romans 13. The Atlantic (15 June) [Online]. Available: https://www.theatlantic.com/ideas/archive/2018/06/romans$13 / 562916 /$.

Nel, M.J. 2021. Reading the New Testament stereoscopically, Scriptura 120.1.

Petrenko, E. and Balode, D. 2021. Past, present and future of biblical scholarship in Latvia, Scriptura 120.1.

Psychology Today. 2021. The replication crisis [Online]. Available: https://www.psychologytoday.com/us/basics/replication-crisis [2021, July 22].

Rogerson, J. 1984. Old Testament criticism in the Nineteenth Century: England and Germany. London: SPCK.

Smith, R. 2021. Time to assume that health research is fraudulent until proven otherwise? The BMJ Opinion (5 July) [Online]. Available:

https://blogs.bmj.com/bmj/2021/07/05/time-to-assume-that-health-research-isfraudulent-until-proved-otherwise/.

Statista Research Department. 2020. Religion in Europe [Online]. Available: https:/www.statista.com/topics/3977/religion-in-europe/.

Stetzer, E. 2015. The Epidemic of Bible Illiteracy in Our Churches. Christianity Today (6 July) [Online]. Available:

https://www.christianitytoday.com/edstetzer/2015/july/epidemic-of-bibleilliteracy-in-our-churches.html.

Tan, S., and Brooks, W. 2019. Theological education as integral component of world mission strategy. In Callaham, S.N. and Brooks, W. (eds.), World mission:

Theology, strategy, and current issues. Bellingham, WA: Lexham Press, 177-203.

Taylor, C. 2007. A secular age. Cambridge, MA: Harvard University Press.

Wright, N.T. 2019. History and eschatology: Jesus and the promise of natural theology. London: SPCK. 